\title{
Expression of the HER-1-4 family of receptor tyrosine kinases in neuroendocrine tumours
}

\author{
RAJAVENTHAN SRIRAJASKANTHAN ${ }^{1}$, TAHIR SHAH ${ }^{1}$, JENNIFER WATKINS ${ }^{2}$, \\ LAURA MARELLI $^{1}$, KORSA KHAN ${ }^{1}$ and MARTYN E. CAPLIN ${ }^{1}$ \\ ${ }^{1}$ Neuroendocrine Tumour Unit and ${ }^{2}$ Histopathology, Royal Free Hospital, London, UK
}

Received August 31, 2009; Accepted October 6, 2009

DOI: 10.3892/or_00000714

\begin{abstract}
The type I receptor tyrosine kinase family comprises four homologous members: Epidermal growth factor receptor (EGFR), HER-2, HER-3 and HER-4. Studies have shown that EGFR and HER-2 play a critical role in oncogenesis. In this study we sought to determine the pattern of expression and the prognostic significance of EGFR, HER-2, HER-3 and HER-4 in a variety of neuroendocrine tumours using immunohistochemistry. HER family receptor expression in 82 paraffin-embedded specimens of neuroendocrine tumours using immunohistochemistry was examined. The pattern and protein expression levels for each receptor were correlated with clinical and pathological parameters. EGFR expression was identified in $86.6 \%$ samples, HER-2 was not expressed in any samples, HER-3 was expressed in 8.5\% samples and HER-4 was expressed $91.5 \%$. EGFR and HER-4 were co-expressed in $79.3 \%$ of cases. HER-3 was correlated with better survival. EGFR was not associated with poor prognosis. This study has demonstrated EGFR, HER-2 and HER-4 expression is not associated with poorer survival. HER-3 expression is correlated with better prognosis. Overexpression of EGFR and HER-4 may offer potential new therapeutic targets.
\end{abstract}

\section{Introduction}

The HER family is comprised of four distinct receptors: EGFR, HER-2, HER-3 and HER-4. These are transmembrane receptors composed of an extracellular ligand-binding domain and a cytoplasmic region with enzymatic activity $(1,2)$. The four HER receptors share an overall structure of two cysteinerich regions in their extracellular region, and a kinase domain flanked by a carboxy-terminal tail with tyrosine auto-

Correspondence to: Dr R. Srirajaskanthan, Neuroendocrine Tumour Unit, Royal Free Hospital, London NW3 2QG, UK

E-mail: rs3856@hotmail.com

Key words: epidermal growth factor receptor, HER-2, HER-3, HER-4, immunohistochemistry, survival, neuroendocrine tumours phosphorylation sites. HER-3 is devoid of intrinsic kinase activity, whilst HER-2 seems to have no direct ligand $(1,3,4)$. Hetero- or homo-dimerism is required for initiation of downstream signalling pathways; since HER-2 has no direct ligand it often heterodimerizes with EGFR or HER-3. Ten possible homo- and hetero-dimers can be formed from HER receptors (1).

To date, ten genes have been identified to encode ligands to this group of receptors. Epidermal growth factor, amphiregulin and transforming growth factor $\alpha$ bind EGFR specifically, whilst neuregulins bind HER-3 and HER-4. Betacellulin, epiregulin bind to both EGFR and HER-4. To transduce signals the receptors need to either hetero- or homo-dimerize following ligand binding (5). HER receptor phosphorylation activates a cascade of signalling pathways that include controlling apoptosis via PKB/Akt and mitogenic pathways via Ras/MAP kinase (6). These routes are thought to regulate cellular growth differentiation, proliferation, angiogenesis and apoptosis. Overexpression of HER family receptors is associated with reduced survival in patients with breast, colon and ovarian cancer (7-11).

Development of humanized antibodies against EGFR and HER-2, have enabled inhibition of the downstream signalling pathways, consequently leading improved survival in these patients $(12,13)$. EGFR inhibition by humanised anti-EGFR antibodies (e.g. cetuximab) have shown positive results in head and neck cancers in combination with radiotherapy. Trastuzumab (herceptin) is a fully humanized monoclonal antibody that binds to the extracellular domain of HER-2 and has anti-proliferative activity against breast cancers overexpressing HER-2 (14).

Neuroendocrine tumours (NETs) have common histopathological characteristics such as expression of chromogranin and synaptophysin (15). These tumours can have a varied clinical behaviour ranging from indolent to aggressive, though the majority are slow growing (16). Knowledge regarding the tumour biology of these tumours is relatively unknown. These tumours are known to express somatostatin receptors which have provided a role for biotherapy with somatostatin analogues. Recent studies have shown that HER family of receptors play a critical role in progression of various cancers (17-19). Previous studies have demonstrated the expression of EGFR in NETs $(13,20)$. We have previously demonstrated high EGFR expression in NETs (13). A number of studies have 
been performed to assess HER-2 expression in a number of different types of NETs, demonstrating different levels of expression in various NETs (21-24). Expression of all four members of the HER family has not been studied in NETs.

The aim of this study was to evaluate the expression of HER-2, HER-3 and HER-4 in neuroendocrine tumours by immunohistochemistry and its association with EGFR and to correlate the extent of expression with clinicopathological parameters.

\section{Materials and methods}

Consecutive samples of formalin-fixed paraffin-embedded tumour tissue were available from 82 patients with a histologically confirmed diagnosis of NET. Of these 58 were from surgical resection from patients who had undergone an operation and tumour resection. A further 24 samples were from tumour biopsies. The study population included all major NET subtypes including: foregut, mid-gut, hindgut, bronchial, paraganglioma and NETs of unknown primary (see Table I). Demographic details, including tumour stage and survival data. Tumours were graded where possible using the TNM system proposed by ENETS consensus group $(25,26)$. Using this classification low grade tumour was regarded as mitotic count $<2$ per 10 high power fields (HPF) and Ki67 $\leq 2 \%$, intermediate grade as having a mitotic count 2-20 per $10 \mathrm{HPF}$ and Ki67 3-20\% and high grade as mitotic count of $>20$ per $10 \mathrm{HPF}$ and Ki67 >20. This classification currently only encompasses gastroenteropancreatic NETs, for the purposes of this study we expanded this to classification to include other types of NETs. The study was performed under the auspices of the Royal Free Hospital Pathology Department ethics recommendation for the studies of archive histology samples.

Three micrometer sections of tumour tissue were dewaxed three times in xylene and rehydrated in ethanol. Endogenous peroxidase activity was blocked by incubation in $1 \%$ hydrogen peroxide, diluted in acetone, for $10 \mathrm{~min}$. For HER-3 antibody studies the samples were submersed in $10 \mathrm{mM}$ citric acid (pH 6.0) and microwaved at 600 watts for $20 \mathrm{~min}$; then allowed to cool at room temperature. Slides for HER-2 and HER-4 studies were immersed in $10 \mathrm{mM}$ citric acid ( $\mathrm{pH}$ 6.0) and placed water-bath at $98^{\circ} \mathrm{C}$ for $45 \mathrm{~min}$, following which they were removed and cooled at room temperature for $20 \mathrm{~min}$. Specimens were washed in TBS-Tween and pre-incubated with avidin and biotin diluted in 3\% normal serum for $20 \mathrm{~min}$ each.

Primary antibodies comprised: anti-HER-2 polyclonal rabbit (Dako Ltd), anti-HER-3 rabbit monoclonal antibody (Dako Ltd), anti-HER-4 polyclonal rabbit antibody (Labvision Ltd). Sections were then incubated with anti-HER-2 antibody (1:250), anti-HER-4 antibody (1:50) and anti-HER-3 antibody (1:50) were incubated for $1 \mathrm{~h}$. Biotinlyated 2 antibody was used with slides incubated for $30 \mathrm{~min}$. The antibody binding was visualized by using a DAB peroxidase substrate kit. The sections were counterstained with Mayer's haematoxylin for $3.5 \mathrm{~min}$.

Negative controls included substitution of the primary antibody via normal sera. Breast cancer tissue was used for positive controls and determining optimal pre-treatment conditions for all antibodies.
Table I. Patient characteristics.

\begin{tabular}{|c|c|c|}
\hline & Number & $\%$ \\
\hline Patients & 82 & \\
\hline \multicolumn{3}{|l|}{ Age } \\
\hline Median & 59 & \\
\hline Range & $32-88$ & \\
\hline \multicolumn{3}{|l|}{ Gender } \\
\hline Male & 33 & 40.2 \\
\hline Female & 49 & 59.3 \\
\hline \multicolumn{3}{|l|}{ Primary site } \\
\hline Thymic & 1 & 1.2 \\
\hline Thyroid & 4 & 4.9 \\
\hline Bronchial & 4 & 4.9 \\
\hline Gastric & 3 & 3.7 \\
\hline Pancreatic & 18 & 23.2 \\
\hline Duodenal & 1 & 1.2 \\
\hline Jejunal-Ileal & 21 & 25.6 \\
\hline Appendiceal & 8 & 9.8 \\
\hline Colon & 4 & 6.1 \\
\hline Ovarian/Cervical & 4 & 4.9 \\
\hline Paraganglioma & 6 & 6.1 \\
\hline Unknown & 8 & 8.5 \\
\hline
\end{tabular}

The EGFR studies (13) were reviewed in this study in order to correlate EGFR immunohistochemical findings with those of HER-2, HER-3 and HER-4. This study initially studied 98 NET specimens, however due to limited availability of tissue we performed immunohistochemical analysis of HER-2, HER-3 and HER-4 in 82 of these cases. The remaining 16 cases which had been stained for EGFR were excluded from our analysis.

Histological interpretation. Tumours were classified according to their site of origin, level of differentiation and their initial mitotic index. Two examiners (R.S. and J.W.) performed the interpretation of immunohistological staining for the antibodies studied independently of each other. Any discordant results were then reviewed together to reach agreement or determine an average value for disputed sections. The same score was achieved independently in $94 \%$ (77/82) of cases. Scoring was based on intensity of staining of tumour cells whereby 0 , negative; 1 , weakly positive; 2 , moderate; 3 , strongly positive. Then extent of tumour staining was also score, whereby 10 random high power fields were assessed and the average percentage of positive staining cells in which: $1,<25 \% ; 2$, $25-75 \%$ and $3,>75 \%$. The product of the density of staining and the percentage of tumour cells staining positive was used as the histological score, giving final values of $0,1,2$, $3,4,6,9$. Scores of $\leq 2$ were counted as negative and scores $>2$ were classed as positive $(13,27)$. 


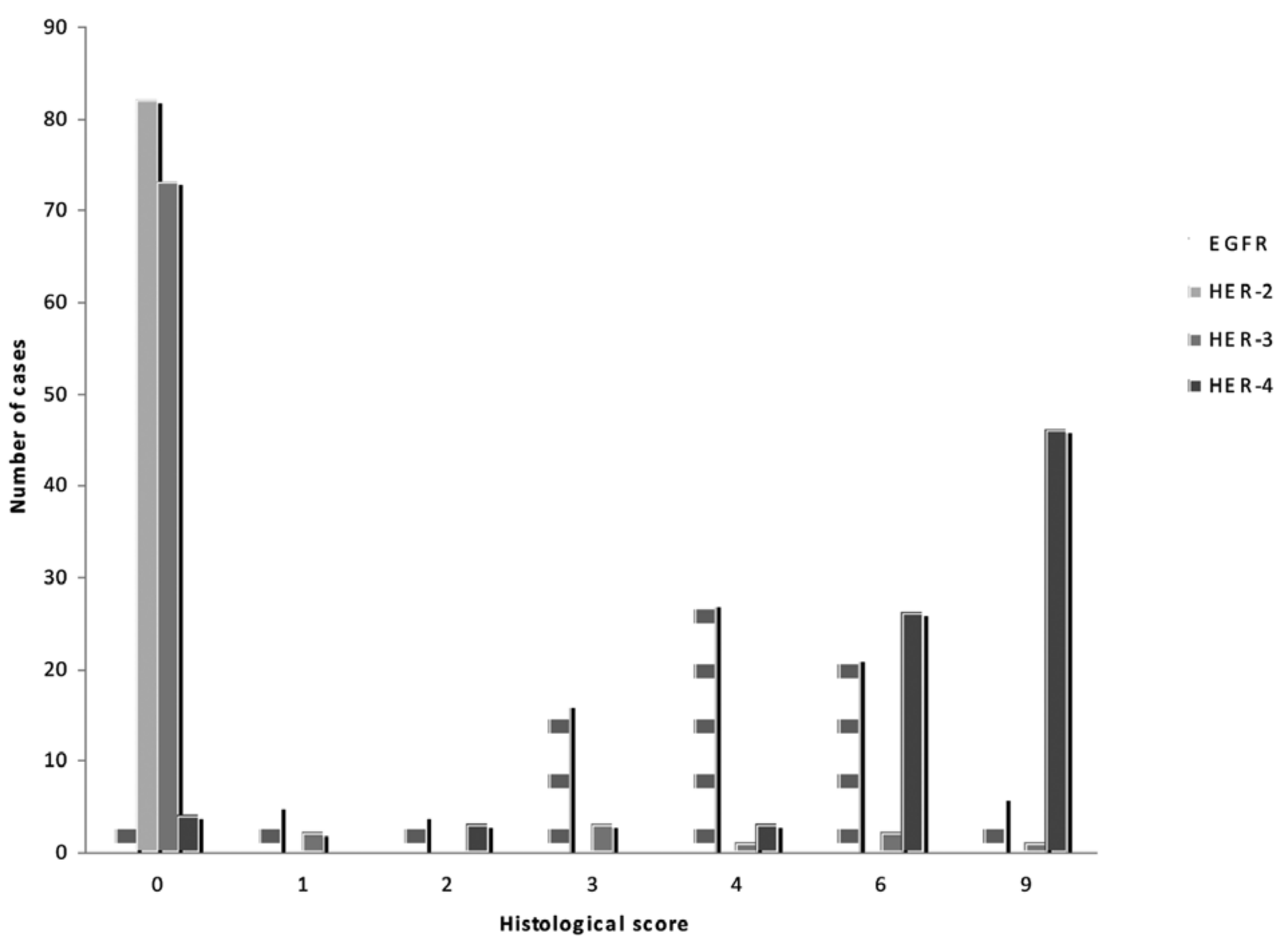

Figure 1. Scoring of tumour samples according to immunohistochemical staining. The method of creating a histological score for immunohistochemical staining is described in Materials and methods.

\section{Results}

Tumour tissue was available from 82 patients with a histologically confirmed diagnosis of NET. All 82 cases were negative for HER-2 (see Fig. 1). Seven (8.5\%) cases were positive for HER-3 staining; the staining in these cases was predominantly cytoplasmic with some membranous staining. The surrounding stroma showed weak or negative staining in the majority of cases. Of the seven cases that were positive, 3 were paragangliomas, 3 foregut and one mid-gut tumour (see Table II). Seventy-five $(91.5 \%)$ cases were positive for HER-4 antibody, with staining predominantly membranous and cytoplasmic (see Fig. 2). Seventy-one of the 82 (86.5\%) cases reviewed for EGFR staining were positive for EGFR expression, the staining of which was predominantly cytoplasmic and perinuclear.

Four cases overexpressed EGFR only, 10 cases expressed only HER-4 receptor and none expressed HER-3 receptor alone. EGFR, HER-3 and HER-4 were all expressed in 6 cases. EGFR and HER-4 were co-expressed in 65 (79.3\%) cases. There minimal weak staining of the surrounding stroma in cases with EGFR, HER-3 and HER-4.

Tumour grade could be assessed in 66 of the 82 cases, who had tissue available for MIB-1 or Ki67 proliferation index staining. Of these 44 were low grade, 6 intermediate grade and 16 high grade. Multivariate statistical analysis did not show any correlation between tumour grade and expression of
EGFR, HER-2, HER-3 or HER-4. There was no correlation of expression of EGFR with HER-3 or HER-4. No correlation between HER-3 and HER-4 expression. There was no significant difference in expression of EGFR, HER-3 or HER-4 between fore-, mid- or hind-gut tumours; with EGFR and HER-4 being co-expressed in all different types of NETS.

HER-3 was positively correlated with survival using Spearman correlation $(\mathrm{r}=0.272, \mathrm{p}=0.05)$. EGFR, HER-2 and HER-4 had no significant correlation with survival (see Table III).

\section{Discussion}

Neuroendocrine tumours occur throughout the body and have a diverse biology ranging from indolent to highly aggressive (16). To date there have been no studies undertaken examining expression of all HER family of receptors in NETs. We have demonstrated that HER-2 is not expressed in NETs, whilst HER-4 is frequently and HER-3 infrequently expressed in NETs. Furthermore, HER-3 is correlated with better prognosis.

Studies examining EGFR expression have noted significantly worse prognosis in NETs expressing EGFR rather than those that do not (20). This does not appear to be the case in our study, with over $>80 \%$ of cases expressing EGFR and these tumours did not show a worse prognosis. A 
Table II. Immunohistochemistry for EGFR, HER-3 and HER-4 in 82 neuroendocrine tumours.

\begin{tabular}{|c|c|c|c|c|c|c|c|c|c|c|}
\hline \multirow[b]{2}{*}{ Site } & \multirow[b]{2}{*}{ No. } & \multicolumn{3}{|c|}{ EGFR } & \multicolumn{3}{|c|}{ HER-3 } & \multicolumn{3}{|c|}{ HER-4 } \\
\hline & & + Case & Intensity & Area & + Case & Intensity & Area & + Case & Intensity & Area \\
\hline Thymic & 1 & 1 & 2 & 3 & 0 & 0 & 0 & 1 & 2 & 3 \\
\hline Thyroid & 4 & 4 & $1-3$ & $1-3$ & 0 & 0 & 0 & 3 & $1-3$ & $2-3$ \\
\hline Bronchial & 4 & 4 & 2 & 2 & 1 & 3 & 1 & 4 & $2-3$ & $2-3$ \\
\hline Gastric & 3 & 3 & 2 & $1-3$ & 0 & 0 & 0 & 3 & 3 & $2-3$ \\
\hline Pancreatic & 18 & 14 & $1-3$ & $1-3$ & 2 & 2 & $1-2$ & 14 & $1-3$ & $1-3$ \\
\hline Duodenal & 1 & 1 & 2 & 3 & 0 & 0 & 0 & 1 & 3 & 3 \\
\hline Jejunal-Ileal & 21 & 19 & $1-3$ & $1-3$ & 1 & 2 & 3 & 19 & $2-3$ & $1-3$ \\
\hline Appendiceal & 8 & 8 & $2-3$ & $1-3$ & 0 & 0 & 0 & 8 & $2-3$ & $2-3$ \\
\hline Colon & 4 & 2 & 2 & 2 & 0 & 0 & 0 & 4 & $2-3$ & $2-3$ \\
\hline Ovarian & 3 & 3 & 2 & 2 & 0 & 0 & 0 & 3 & $2-3$ & 2 \\
\hline Cervical & 1 & 1 & 2 & 2 & 0 & 0 & 0 & 1 & $2-3$ & 2 \\
\hline Paraganglioma & 6 & 5 & $1-3$ & $1-3$ & 3 & $1-3$ & $2-3$ & 6 & $2-3$ & $2-3$ \\
\hline Unknown & 8 & 6 & $1-3$ & $1-3$ & 0 & 0 & 0 & 8 & $1-3$ & $2-3$ \\
\hline Total & 82 & 71 & & & 7 & & & 75 & & \\
\hline
\end{tabular}

No, is number of cases in total; + , case is the number of cases with positive uptake (i.e. score $>2$ ). Intensity scored 1-3, where: 1 , weak; 2 , moderate and 3 , intense. Area scored $1-3$, where $1,<25 \% ; 2,25-75 \%$ and $3,>75 \%$.
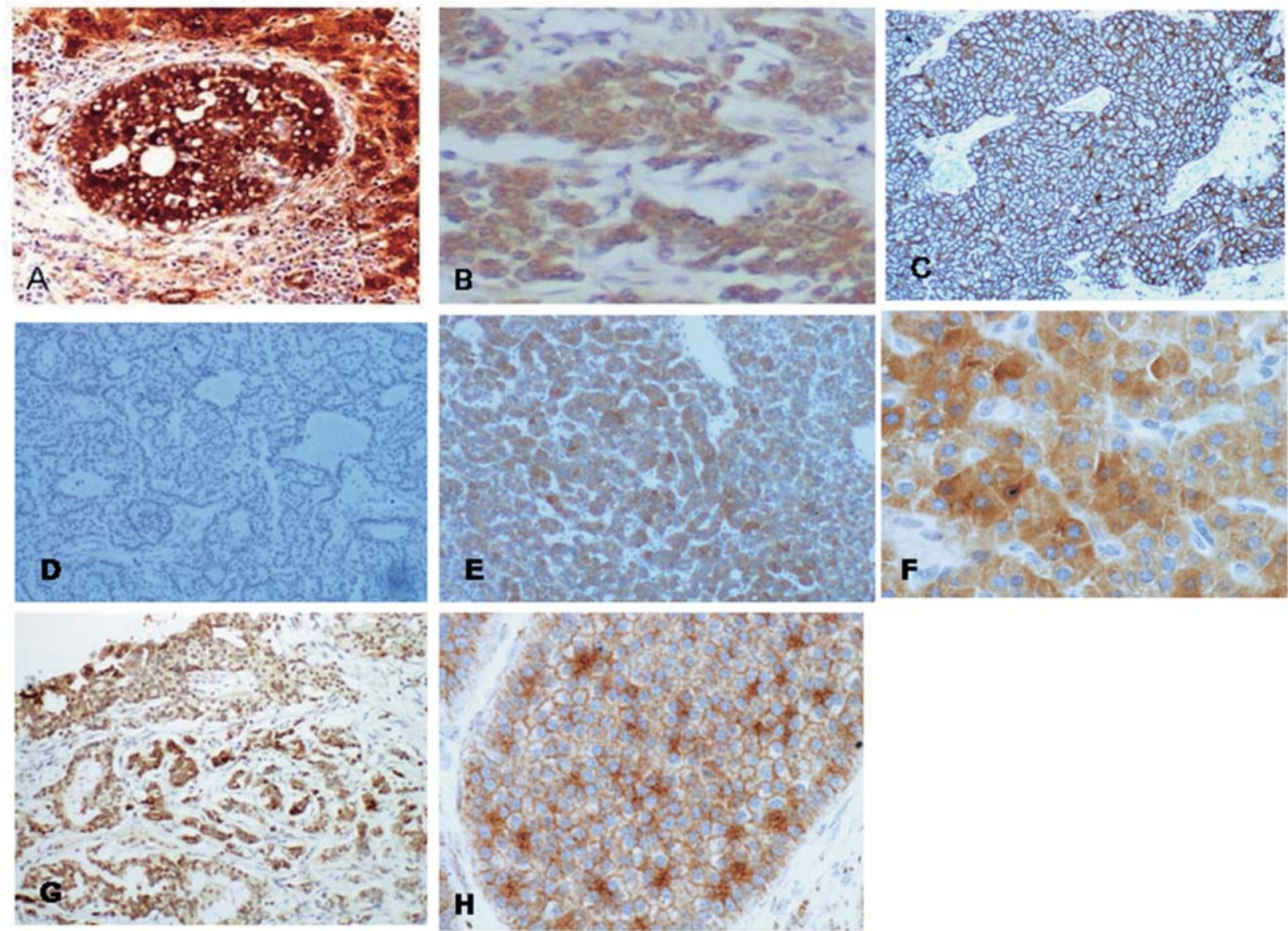

Figure 2. (A) EGFR staining of NET, predominantly cytoplasmic and membranous staining, x200 magnification. (B) EGFR staining x400 magnification. (C) HER-2 staining of breast tumour, predominantly membranous staining, x200 magnification. (D) HER-2 in NET, no evidence of staining, x200 magnification. (E) HER-3 predominantly cytoplasmic with some membranous staining in NET, x200. (F) HER-3 staining of ileal NET, x400 magnification. (G) HER-4 with predominantly membranous and some cytoplasmic staining in NET, x200 magnification. (H) HER-4 staining predominantly membranous pattern, $\mathrm{x} 400$ magnification. 
Table III. Correlation for a cohort of 82 patients with neuroendocrine tumours.

HER-1 HER-3 HER-4

\begin{tabular}{lllll}
\hline HER-2 & Correlation coefficient & 0.086 & -0.103 & $-0.505^{\mathrm{b}}$ \\
& Sig. (two-tailed) & 0.447 & 0.364 & 0.000 \\
HER-3 & Correlation coefficient & 0.042 & & 0.079 \\
& Sig. (two-tailed) & 0.712 & & 0.483 \\
HER-4 & Correlation coefficient & 0.047 & 0.079 & \\
& Sig. (two-tailed) & 0.681 & 0.483 & \\
Survival & Correlation coefficient & 0.010 & $0.272^{\mathrm{a}}$ & 0.194 \\
& Sig. (two-tailed) & 0.937 & 0.032 & 0.130 \\
\hline
\end{tabular}

${ }^{a}$ Significant correlation between HER-3-positive tumours and longer survival. ${ }^{\mathrm{b} H E R}-2$ and HER-4 had a negative correlation.

study by Atkins et al has demonstrated that immunohistochemical expression of EGFR can vary with age of tissue samples (28), however, in our study the percentage of EGFR-positive tumours did not differ between samples more or $<2$ years old.

HER-2 receptor expression has been demonstrated in intestinal but not gastric NETs by Yamaguchi et al (23), this study used the same Dako antibody though the secondary antibody and duration of incubation of primary antibody is not reported. The reasons for this difference in staining are unclear and may be related to the age of the slides or the scoring system used to interpret the slides. Other studies have also demonstrated variable expression of HER-2 in NETs using immunohistochemical and PCR techniques $(21,22,29)$. The negative expression of HER-2 immunohistochemistry in this study could be due to a number of reasons; possibly related to low levels of receptor expression in these specimens which were below the threshold of detection by immunohistochemistry.

HER-2 was not expressed in any of the cases, which is of interest since cell line studies have shown that HER-2 is the preferred dimer partner for other receptors (30). Even though HER-2 does not act as a receptor for EGF, it can decrease the rate of ligand dissociation from the cognate receptor, EGFR (31). This results in stronger and more prolonged activation of the EGFR signalling network (2). Furthermore, in cell line studies, mitogenic signaling appears to be stronger via HER-2 containing heterodimers than any other heterodimers $(2,32)$. All these factors lead to a stronger more prolonged signaling response following activation of HER-2 receptors.

Wang et al, demonstrated HER-3 expression in 6 of 98 (6\%) malignant GEP NETs (22). Our study identified HER-3 positivity in 6\% of GEP NETs (3 of 52 cases) and 50\% (3 of 6 cases) of paragangliomas. This confirms that HER-3 is infrequently expressed in NETs. HER-3 expression correlated with improved survival, however, only 7 cases showed expression of HER-3, furthermore 3 of these cases were in paragangliomas which generally have a more indolent course than GEP NETs. HER-3 overexpression has been associated with improved outcome with breast cancer in one study (33). Further HER-3-positive cases need to be evaluated to confirm whether this is a consistent finding. Interestingly, $50 \%$ of paraganglioma cases expressed HER-3, again a study of more paraganglioma cases need to be performed to confirm this finding.

Studies performed looking at HER family of receptor expression in other cancers, have often found that HER-4 expression is associated with positive prognostic survival. This study has not demonstrated expression of HER-4 to be associated with an improved prognosis. Currently the role of HER-4 in NET biology is not understood and with further understanding of its interactions with other members of the HER family and downstream signaling effects we may be able to develop better understanding.

Co-expression of EGFR receptors appears to vary from different tumour groups; however, EGFR and HER-4 coexpression was identified in $2.3 \%$ of colonic adenocarcinoma (11) and $13.6 \%$ of non-small cell lung carcinomas (7). There is currently no evidence that co-expression of EGFR and HER-4 is associated with alteration in prognosis.

Expression of only a single receptor was uncommon, with only 4 cases expressing EGFR alone and HER-4 was expressed in ten cases. One reason for this may be that receptor expression may have been below the threshold level of immunohistochemical detection. HER-3 was not expressed alone, which is unsurprising since it has no intrinsic tyrosine kinase activity (34). Co-expression of EGFR and HER-4 has been demonstrated in other tumours (7). HER-2 co-expression is often linked with HER-3 expression, in this study HER-2 expression was absent in these tumour samples and HER-3 was rarely expressed.

This is the first study to demonstrate co-expression of the EGFR family of receptors. Importantly the high expression of EGFR may provide a possible therapeutic target for antiEGFR therapy with chimeric monoclonal antibodies (35). Phase II clinical studies are underway looking at Gefitinib in NETs, there preliminary results showed initial progressionfree survival, however, no objective clinical response $(36,37)$. It has been postulated that the low response is due to the fact that other signaling pathways are activated following inhibition of EGFR receptor (38). There is evidence that strength of EGFR expression does not correlate to response to EGFR inhibitors (39), furthermore, EGFR-negative tumours have been shown to be responsive to EGFR inhibitors $(38,40)$.

With the development of HER-4 monoclonal antibody therapy, the high expression of this receptor in NETs may provide a possible role for molecular targeted therapy. However, the actual role of HER-4 in tumourogenesis is unclear, with some evidence supporting its role as an antitumoural receptor, with overexpression associated with positive prognostic value $(17,41)$. Studies in breast cancer have shown conflicting results with some studies associating HER-4 expression with short survival and others with longer survival $(10,17,42)$. Further study needs to be done to understand the downstream signaling that occurs following activation of HER-4. 
In conclusion, this study demonstrates that EGFR, HER-3, HER-4 are expressed in neuroendocrine tumours. HER-3 expression was associated with better survival, though the number of cases was small and also paragangliomas have a different prognosis than GEP NETs. The lack of expression of HER-2 may in part explain the less aggressive clinical course of these tumours. Recent development of pan-HER receptor inhibitors may provide possible therapeutic options in NETs.

\section{References}

1. Roskoski R Jr: The ErbB/HER receptor protein-tyrosine kinases and cancer. Biochem Biophys Res Commun 18: 1-11, 2004.

2. Yarden Y: The EGFR family and its ligands in human cancer. Signalling mechanisms and therapeutic opportunities. Eur J Cancer 37 (Suppl 4): S3-S8, 2001.

3. Citri A, Skaria KB and Yarden Y: The deaf and the dumb: the biology of ErbB-2 and ErbB-3. Exp Cell Res 10: 54-65, 2003.

4. Casalini P, Iorio MV, Galmozzi E and Menard S: Role of HER receptors family in development and differentiation. J Cell Physiol 200: 343-350, 2004.

5. Yarden Y and Sliwkowski MX: Untangling the ErbB signalling network. Nat Rev Mol Cell Biol 2: 127-137, 2002.

6. Gullick WJ: The Type 1 growth factor receptors and their ligands considered as a complex system. Endocr Relat Cancer 8: 75-82, 2001

7. Koutsopoulos AV, Mavroudis D, Dambaki KI, Souglakos J, Tzortzaki EG, Drositis J, Delides GS, Georgoulias V and Stathopoulos EN: Simultaneous expression of c-erbB-1, c-erbB-2, c-erbB-3 and c-erbB-4 receptors in non-small-cell lung carcinomas: correlation with clinical outcome. Lung Cancer 57: 193-200, 2007

8. Leibl S, Bodo K, Gogg-Kammerer M, Hrzenjak A, Petru E, Winter R, Denk $\mathrm{H}$ and Moinfar F: Ovarian granulosa cell tumors frequently express EGFR (Her-1), Her-3, and Her-4: an immunohistochemical study. Gynecol Oncol 101: 18-23, 2006

9. Tanner B, Hasenclever D, Stern K, Schormann W, Bezler M, Hermes M, Brulport M, Bauer A, Schiffer IB, Gebhard S, Schmidt M, Steiner E, Sehouli J, Edelmann J, Lauter J, Lessig R, Krishnamurthi K, Ullrich A and Hengstler JG: ErbB-3 predicts survival in ovarian cancer. J Clin Oncol 24: 4317-4323, 2006.

10. Witton CJ, Reeves JR, Going JJ, Cooke TG and Bartlett JM: Expression of the HER1-4 family of receptor tyrosine kinases in breast cancer. J Pathol 200: 290-297, 2003.

11. Kountourakis P, Pavlakis K, Psyrri A, Rontogianni D, Xiros N, Patsouris E, Pectasides D and Economopoulos T: Prognostic significance of HER3 and HER4 protein expression in colorectal adenocarcinomas. BMC Cancer 6: 46, 2006.

12. Kamath $\mathrm{S}$ and Buolamwini JK: Targeting EGFR and HER-2 receptor tyrosine kinases for cancer drug discovery and development. Med Res Rev 26: 569-594, 2006.

13. Shah T, Hochhauser D, Frow R, Quaglia A, Dhillon AP and Caplin ME: Epidermal growth factor receptor expression and activation in neuroendocrine tumours. J Neuroendocrinol 18: 355-360, 2006

14. De Laurentiis M, Cancello G, Zinno L, Montagna E, Malorni L, Esposito A, Pennacchio R, Silvestro L, Giuliano M, Giordano A, Caputo F, Accurso A and De PS: Targeting HER2 as a therapeutic strategy for breast cancer: a paradigmatic shift of drug development in oncology. Ann Oncol 16 (Suppl 4): iv7-iv13, 2005 .

15. Modlin IM, Oberg K, Chung DC, Jensen RT, de Herder WW, Thakker RV, Caplin M, Delle FG, Kaltsas GA, Krenning EP, Moss SF, Nilsson O, Rindi G, Salazar R, Ruszniewski P and Sundin A: Gastroenteropancreatic neuroendocrine tumours. Lancet Oncol 9: 61-72, 2008.

16. Caplin ME, Buscombe JR, Hilson AJ, Jones AL, Watkinson AF and Burroughs AK: Carcinoid tumour. Lancet 352: 799-805, 1998

17. Sassen A, Rochon J, Wild P, Hartmann A, Hofstaedter F, Schwarz S and Brockhoff G: Cytogenetic analysis of HER1/ EGFR, HER2, HER3 and HER4 in 278 breast cancer patients. Breast Cancer Res 8: R2, 2008.
18. Schmelz EM, Xu H, Sengupta R, Du J, Banerjee S, Sarkar FH, Rishi AK and Majumdar AP: Regression of early and intermediate stages of colon cancer by targeting multiple members of the EGFR family with EGFR-related protein. Cancer Res 67: 5389-5396, 2007.

19. Smeenk HG, Erdmann J, van DH, van MR, Hop WC, Jeekel J and van Eijck $\mathrm{CH}$ : Long-term survival after radical resection for pancreatic head and ampullary cancer: a potential role for the EGF-R. Dig Surg 24: 38-45, 2007.

20. Papouchado B, Erickson LA, Rohlinger AL, Hobday TJ, Erlichman C, Ames MM and Lloyd RV: Epidermal growth factor receptor and activated epidermal growth factor receptor expression in gastrointestinal carcinoids and pancreatic endocrine carcinomas. Mod Pathol 18: 1329-1335, 2005.

21. Goebel SU, Iwamoto M, Raffeld M, Gibril F, Hou W, Serrano J and Jensen RT: Her-2/neu expression and gene amplification in gastrinomas: correlations with tumor biology, growth, and aggressiveness. Cancer Res 62: 3702-3710, 2002.

22. Wang DG, Johnston CF and Buchanan KD: Oncogene expression in gastroenteropancreatic neuroendocrine tumors: implications for pathogenesis. Cancer 80: 668-675, 1997.

23. Yamaguchi $M$, Hirose $\mathrm{K}$ and Hirai N: HER2 expression in gastrointestinal carcinoid tumors: high in intestinal but not in gastric tumors. Surg Today 37: 270-271, 2007.

24. Roncalli M, Springall DR, Varndell IM, Gaitonde VV, Hamid Q, Ibrahim NB, Grimelius L, Wilander E, Polak JM and Coggi G: Oncoprotein immunoreactivity in human endocrine tumours. J Pathol 163: 117-127, 1991.

25. Rindi G, Kloppel G, Alhman H, Caplin M, Couvelard A, de Herder WW, Erikssson B, Falchetti A, Falconi M, Komminoth P, Korner M, Lopes JM, McNicol AM, Nilsson O, Perren A, Scarpa A, Scoazec JY and Wiedenmann B: TNM staging of foregut (neuro)endocrine tumors: a consensus proposal including a grading system. Virchows Arch 449: 395-401, 2006.

26. Rindi G, Kloppel G, Couvelard A, Komminoth P, Korner M, Lopes JM, McNicol AM, Nilsson O, Perren A, Scarpa A, Scoazec JY and Wiedenmann B: TNM staging of midgut and hindgut (neuro) endocrine tumors: a consensus proposal including a grading system. Virchows Arch 451: 757-762, 2007.

27. Iddon J, Bundred NJ, Hoyland J, Downey SE, Baird P, Salter D, McMahon R and Freemont AJ: Expression of parathyroid hormone-related protein and its receptor in bone metastases from prostate cancer. J Pathol 191: 170-174, 2000.

28. Atkins D, Reiffen KA, Tegtmeier CL, Winther H, Bonato MS and Storkel S: Immunohistochemical detection of EGFR in paraffin-embedded tumor tissues: variation in staining intensity due to choice of fixative and storage time of tissue sections. J Histochem Cytochem 52: 893-901, 2004.

29. Evers BM, Rady PL, Sandoval K, Arany I, Tyring SK, Sanchez RL, Nealon WH, Townsend CM Jr and Thompson JC: Gastrinomas demonstrate amplification of the HER-2/neu protooncogene. Ann Surg 219: 596-601, 1994.

30. Graus-Porta D, Beerli RR, Daly JM and Hynes NE: ErbB-2, the preferred heterodimerization partner of all ErbB receptors, is a mediator of lateral signaling. EMBO J 16: 1647-1655, 1997.

31. Karunagaran D, Tzahar E, Beerli RR, Chen X, Graus-Porta D, Ratzkin BJ, Seger R, Hynes NE and Yarden Y: ErbB-2 is a common auxiliary subunit of NDF and EGF receptors: implications for breast cancer. EMBO J 15: 254-264, 1997.

32. Lenferink AE, Pinkas-Kramarski R, Van de Poll ML, Van Vugt MJ, Klapper LN, Tzahar E, Waterman H, Sela M, Van Zoelen EJ and Yarden Y: Differential endocytic routing of homo- and hetero-dimeric ErbB tyrosine kinases confers signaling superiority to receptor heterodimers. EMBO J 17: 3385-3397, 1998.

33. Pawlowski V, Revillion F, Hebbar M, Hornez L and Peyrat JP: Prognostic value of the type I growth factor receptors in a large series of human primary breast cancers quantified with a realtime reverse transcription-polymerase chain reaction assay. Clin Cancer Res 6: 4217-4225, 2000.

34. Hellyer NJ, Cheng K and Koland JG: ErbB3 (HER3) interaction with the p85 regulatory subunit of phosphoinositide 3-kinase. Biochem J 333: 757-763, 1998.

35. Hopfner M, Sutter AP, Gerst B, Zeitz M and Scherubl H: A novel approach in the treatment of neuroendocrine gastrointestinal tumours. Targeting the epidermal growth factor receptor by gefitinib (ZD1839). Br J Cancer 89: 1766-1775, 2003. 
36. Duran I, Salazar R, Casanovas O, Arrazubi V, Vilar E, Siu LL, Yao $\mathrm{J}$ and Tabernero J: New drug development in digestive neuroendocrine tumors. Ann Oncol 18: 1307-1313, 2007.

37. Hobday TJ, Mahoney M and Erlichman C: Preliminary results of a phase II trial of gefitinib in progressive metastatic neuroendocrine tumors (NET): a Phase II Consortium (P2C) study. J Clin Oncol 23: 4083, 2005.

38. Arteaga CL: Epidermal growth factor receptor dependence in human tumors: more than just expression? Oncologist 7 (Suppl 4): 31-39, 2002

39. Ciardiello F: Epidermal growth factor receptor tyrosine kinase inhibitors as anticancer agents. Drugs 60 (Suppl 1): 25-32, 2000 .
40. Perez-Soler R, Kemp B, Wu QP, Mao L, Gomez J, ZeleniuchJacquotte A, Yee H, Lee JS, Jagirdar J and Ling YH: Response and determinants of sensitivity to paclitaxel in human non-small cell lung cancer tumors heterotransplanted in nude mice. Clin Cancer Res 6: 4932-4938, 2000.

41. Gullick WJ: c-erbB-4/HER4: friend or foe? J Pathol 200: 279-281, 2003.

42. Tsutsui S, Ohno S, Murakami S, Kataoka A, Kinoshita J and Hachitanda Y: Prognostic significance of the coexpression of p53 protein and c-erbB2 in breast cancer. Am J Surg 185: 165-167, 2003. 